\title{
The immunomodulatory properties of probiotic microorganisms beyond their viability (ghost probiotics: proposal of paraprobiotic concept)
}

\author{
Valentina Taverniti $\cdot$ Simone Guglielmetti
}

Received: 13 February 2011/Accepted: 24 March 2011/Published online: 16 April 2011

(C) Springer-Verlag 2011

\begin{abstract}
The probiotic approach represents a potentially effective and mild alternative strategy for the prevention and treatment of either inflammatory or allergic diseases. Several studies have shown that different bacterial strains can exert their probiotic abilities by influencing the host's immune system, thereby modulating immune responses. However, the emerging concern regarding safety problems arising from the extensive use of live microbial cells is enhancing the interest in non-viable microorganisms or microbial cell extracts, as they could eliminate shelf-life problems and reduce the risks of microbial translocation and infection. The purpose of this review is to provide an overview of the scientific literature concerning studies in which dead microbial cells or crude microbial cell fractions have been used as health-promoting agents. Particular attention will be given to the modulation of host immune responses. Possible mechanisms determining the effect on the immune system will also be discussed. Finally, in the light of the FAO/WHO definition of probiotics, indicating that the word 'probiotic' should be restricted to products that contain live microorganisms, and considering the scientific evidence indicating that inactivated microbes can positively affect human health, we propose the new term 'paraprobiotic' to indicate the use of inactivated microbial cells or cell fractions to confer a health benefit to the consumer.
\end{abstract}

Keywords Paraprobiotic Probiotic . Immunomodulation · Lactobacillus $\cdot$ Bifidobacterium

V. Taverniti · S. Guglielmetti $(\square)$

Department of Food Science and Microbiology (DiSTAM),

Università degli Studi di Milano, Via Celoria 2,

20133 Milan, Italy

e-mail: simone.guglielmetti@unimi.it

\section{Introduction}

A basic Google Internet search (executed on 21 January 2011) yielded approximately 6 million results for the word 'probiotic'. About 7500 scientific references were listed for the same word by PubMed, more than $20 \%$ of which appeared in 2010. These simple data indicate the growing interest in the field of probiotic microorganisms and products, which supports a global market that generated $\$ 15.9$ billion in 2008 and is expected to be worth $\$ 19.6$ billion in 2013 (BCC Research 2008).

The majority of the scientific reports define probiotics according to the definition recommended by an FAO/WHO workshop conducted in 2002, which describes probiotics as 'live microorganisms which when administered in adequate amounts confer a health benefit on the host' (FAO/ WHO 2002). This definition specifies that probiotic microorganisms must be 'live', and this stipulation is supported by an extensive number of studies suggesting that to provide health benefits, probiotic microorganisms must be viable (Gobbetti et al. 2010). Nevertheless, scientific evidence indicating that inactivated microbes positively affect human health can also be found in the literature (Kataria et al. 2009). Accordingly, products intentionally containing non-viable microbial cells are already present in the market (e.g. Lactéol Fort from PUMC Pharmaceutical Co., Ltd and Fermenti Lattici Tindalizzati from Frau, AF United S.p.a.).

The mechanisms underlying probiotic effects are generally attributed to the interaction of probiotics with other microorganisms (members of the microbiota or pathogens) or to the cross-talk of probiotics with host cells. The former type of interaction is typically (though not exclusively) dependent on the viability of probiotic cells, since it is exerted by competitive exclusion (competition for nutrients 
or adhesion sites), direct inhibition of certain microorganisms (production of antimicrobial molecules) or increased growth of healthy components of the microbiota (nutritional or environmental proto-cooperation). In contrast, direct interaction with the host can be mediated by bacterial cells independent of their viability and is based on the capacity of human cells to recognise specific bacterial components or products, giving rise to responses that commonly involve the mucosa-associated lymphoid tissue (MALT) and, therefore, the immune system (Adams 2010).

The purpose of this review is to provide an overview of the scientific literature concerning studies in which nonviable microbial cells or crude microbial cell fractions have been investigated as health-promoting agents. In particular, attention will focus on the modulation of host immune responses, as this modulation is the primary means by which components of dead cells are believed to exert their bioactivities (Adams 2010). Possible mechanisms determining the effect on the immune system will be discussed based on studies that have demonstrated particular bacterial structural molecules or components to activate specific immune responses (Table 1).

\section{What is wrong with dead probiotic cells? Gain from loss}

Starting from the fundamental requirement specified by the FAO/WHO definition for probiotics described above, the viability of bacterial cells represents an essential condition that guarantees the beneficial effects of probiotics on host health. Nevertheless, it cannot be discounted that in several circumstances, the advantages of using live bacterial cells could be counterbalanced by safety risks. For instance, it has been widely demonstrated that probiotics represent a potential effective alternative in the treatment of inflammatory and auto-immune gastrointestinal diseases due to their beneficial effects in modulating the immune response (Fedorak and Madsen 2004a). However, the administration of viable bacterial cells to individuals with weaker immune systems, enhanced inflammatory responses and/or compromised mucosal barrier functions could turn 'generally recognised as safe' harmless probiotic bacteria into detrimental microorganisms (Besselink et al. 2008). Therefore, the use of killed/inactivated bacteria, as long as the beneficial effects are retained, would represent an advantage because it is possible to make these bacteria potentially harmless through a tailored inactivation treatment. It is clear that from this new and wider perspective, many aspects should be considered. For example, there should be careful monitoring of the effects that different types of inactivation treatments have on bacterial structure and components (Ananta and Knorr 2009) and on maintenance of probiotic properties, both quantitatively and qualitatively.

\section{Immunomodulatory properties of viable versus inactivated probiotic cells}

The first experiment required to understand the potential usefulness of non-viable bacteria as health-promoting agents should be a comparison of the effects of live versus killed cells of the same probiotic strain. Interestingly, this kind of analysis has yielded contradictory results. Some studies observed a more potent immunostimulatory activity of live bacteria when compared with killed cells (Miettinen et al. 1996; Haller et al. 2000). However, the method of bacterial inactivation is critical to correctly interpret these results. In the work by Miettinen et al. (1996), for instance, bacteria were fixed with glutaraldehyde, which kills cells by cross-linking proteins; this type of treatment denatures and changes the conformation of proteins, potentially leading to altered interaction of bacterial cell surface components with the host immune cells. Furthermore, the method of inactivation can disrupt the bacterial cells, allowing for the potential interaction of intracellular bioactive bacterial compounds with host cells upon administration. A published example of this interaction is discussed later in this review.

Apart from the inactivation method, the immunological target or model system can greatly impact on the observed results. For example, in a study by Cross et al. (2004), heatinactivated Lactobacillus casei Shirota was marginally less effective in inducing some proinflammatory cytokines, such as interleukin (IL)-12 and tumour necrosis factor (TNF)- $\alpha$, than viable cells, whereas IL-10 induction was the same between inactivated and viable cells. In the same study, live cells of the Gram-negative probiotic strain, Escherichia coli Nissle 1917, induced a significantly higher level of proinflammatory cytokines and IL-10 in the murine J774A monocyte/macrophage cell line when compared with heat-killed cells.

In contrast, the effect observed using live bacterial cells has also been noted in the corresponding inactivated cells. For instance, Ryan and collaborators found that living Lactobacillus salivarius UCC118 and UCC119 cells were required for inhibiting the growth of Helicobacter pylori (Ryan et al. 2008); nevertheless, they subsequently demonstrated that there was no difference between the abilities of viable $L$. salivarius cells and cells killed by UV treatment to inhibit the production of IL-8 induced in gastric epithelial cells upon $H$. pylori infection. Notably, strain UCC118 retained the same anti-inflammatory properties of viable cells. On the basis of the latter data, the authors concluded that the immunomodulatory properties were not a result of adhesion to epithelial cells or bacteriocin production (Ryan et al. 2008).

Another study found that both UV-killed Lactobacillus rhamnosus GG (LGG) and the Bifidobacterium breve 
Table 1 Non-viable probiotic microorganisms or probiotic cell components demonstrated to elicit an immune response

\begin{tabular}{|c|c|c|c|c|c|}
\hline Probiotic microorganism & $\begin{array}{l}\text { Inactivation } \\
\text { treatment }\end{array}$ & $\begin{array}{l}\text { Bacterial } \\
\text { component(s) }\end{array}$ & Type study & Immune response elicited & References \\
\hline L. casei Shirota & Heat & $W B C$ & $\begin{array}{l}\text { Mouse J774A monocyte/ } \\
\text { macrophage cell line }\end{array}$ & $\oplus$ IL-12, TNF- $\alpha$, IL10 & $\begin{array}{l}\text { Cross et al. } \\
2004\end{array}$ \\
\hline L. casei Shirota & Heat & $W B C$ & $\begin{array}{l}\text { BALB/c mice fed with bacteria } \\
\text { and then injected with OVA } \\
\text { (in vivo) }\end{array}$ & $\begin{array}{l}\downarrow \text { OVA-specific IgE; } \\
\text { in splenocytes: } \\
\downarrow \text { IL-4, IL-5, IL-6; } \\
\oplus \text { IFN- } \gamma, \text { IL-2 }\end{array}$ & $\begin{array}{l}\text { Matsuzaki } \\
\text { and Chin } \\
2000\end{array}$ \\
\hline L. casei Shirota & Heat & $W B C$ & $\begin{array}{l}\text { C57BL/6 mice presensitised by } \\
\text { epicutaneous patching with } \\
\text { Der p } 2 \text { and then fed with } \\
\text { bacteria (in vivo) } \\
\text { Splenic T cells from C57BL/6 } \\
\text { mice fed with bacteria } \\
\text { (in vivo) }\end{array}$ & $\begin{array}{l}\downarrow \text { IL-5, IL-13, IL-4 } \\
\text { TNF- } \alpha, \text { IFN- } \gamma\end{array}$ & $\begin{array}{l}\text { Lim et al. } \\
2009\end{array}$ \\
\hline $\begin{array}{l}\text { L. acidophilus A2 } \\
\text { L. gasseri A5 } \\
\text { L. salivarius A6 }\end{array}$ & Heat & $W B C$ & Mouse splenocytes & $\oplus \mathrm{IL}-10, \mathrm{IL}-12 \mathrm{p} 70, \mathrm{IFN}-\gamma$ & $\begin{array}{l}\text { Chuang et al. } \\
2007\end{array}$ \\
\hline L. plantarum L-137 & Heat & $W B C$ & $\begin{array}{l}\mathrm{DBA} / 2 \text { mice fed a casein diet, } \\
\text { then intraperitoneally } \\
\text { administered with bacteria }\end{array}$ & $\begin{array}{l}\downarrow \text { casein-specific IgE; } \\
\oplus \text { plasma level IL-12 }\end{array}$ & $\begin{array}{l}\text { Murosaki } \\
\text { et al. } 1998\end{array}$ \\
\hline \multirow[t]{2}{*}{ L. acidophilus L-92 } & \multirow[t]{2}{*}{ Heat } & \multirow[t]{2}{*}{$W B C$} & $\begin{array}{l}\text { BALB/c mice after OVA } \\
\text { immunisation (in vivo) }\end{array}$ & $\begin{array}{l}\downarrow \text { OVA-specific IgE; } \\
\oplus \text { IFN- } \gamma, \text { reduction in Th2 } \\
\text { cytokines in splenocytes }\end{array}$ & \multirow[t]{2}{*}{$\begin{array}{l}\text { Torii et al. } \\
2007\end{array}$} \\
\hline & & & $\begin{array}{l}\text { Mouse Peyer's patches after } \\
\text { oral administration of } \\
\text { bacteria (in vivo) }\end{array}$ & $\oplus$ TGF- $\beta$ and total $\operatorname{IgA}$ & \\
\hline $\begin{array}{l}\text { Bifidobacterium sp., } \\
\text { L. acidophilus } \\
\text { L. casei } \\
\text { L. delbrueckii subsp. bulgaricus } \\
\text { L. gasseri } \\
\text { L. helveticus } \\
\text { L. reuteri } \\
\text { Streptococcus thermophilus }\end{array}$ & Heat & $\begin{array}{l}W B C, \text { cell wall } \\
\text { components } \\
\text { and } \\
\text { cytoplasmic } \\
\text { extracts }\end{array}$ & $\begin{array}{l}\text { Mouse RAW } 264.7 \\
\text { macrophages }\end{array}$ & $\oplus \mathrm{TNF}-\alpha, \mathrm{IL}-6, \mathrm{NO}$ & $\begin{array}{l}\text { Tejada-Simon } \\
\text { and Pestka } \\
1999\end{array}$ \\
\hline L. salivarius UCC118 & UV & $W B C$ & $\begin{array}{l}\text { Human AGS Gastric epithelial } \\
\text { cells }\end{array}$ & $\begin{array}{l}\downarrow \text { IL-8 upon Helicobacter } \\
\text { pylori infection }\end{array}$ & $\begin{array}{l}\text { Ryan et al. } \\
2008\end{array}$ \\
\hline L. rhamnosus GG & UV & $W B C$ & Human Caco-2 cell line & $\begin{array}{l}\downarrow \text { IL-8 by decreasing } \\
\text { Ub-I } \kappa \mathrm{B}\end{array}$ & $\begin{array}{l}\text { Lopez et al. } \\
2008\end{array}$ \\
\hline $\begin{array}{l}\text { Bifidobacterium breve } \mathrm{Bb} 1 \text { and } \\
\mathrm{Bb} 2 ; \text { L. rhamnosus } \mathrm{GG}\end{array}$ & UV & $W B C$ & $\begin{array}{l}\text { Human peripheral blood } \\
\text { mononuclear cells }\end{array}$ & $\begin{array}{l}\oplus \text { IL-12, IFN- } \gamma, \text { TNF- } \alpha, \\
\text { IL-10; } \\
\downarrow \text { IL13 }\end{array}$ & $\begin{array}{l}\text { van Hoffen } \\
\text { et al. } 2010\end{array}$ \\
\hline \multirow[t]{2}{*}{ VSL\#3 bacterial mix } & \multirow[t]{2}{*}{ Sonication } & \multirow[t]{2}{*}{$W B C$} & $\begin{array}{l}\text { Splenocytes from mice } \\
\text { sensitised with Par j } 1 \\
\text { (in vivo) }\end{array}$ & $\oplus \mathrm{IL}-10, \mathrm{IFN}-\gamma$ & \multirow[t]{2}{*}{$\begin{array}{l}\text { Mastrangeli } \\
\text { et al. } 2009\end{array}$} \\
\hline & & & $\begin{array}{l}\text { Prophylactic intranasal } \\
\text { administration in mice } \\
\text { (in vivo) }\end{array}$ & $\begin{array}{l}\downarrow \text { serum antigen-specific } \\
\text { IgG1; } \\
\downarrow \text { IL-13 and IL-4 mRNA; } \\
\oplus \text { IL-10 expression in the } \\
\text { lungs }\end{array}$ & \\
\hline Escherichia coli Nissle 1917 & $\begin{array}{l}\text { Low } \\
\text { temperature }\end{array}$ & $W B C$ & $\begin{array}{l}\text { Peripheral blood mononuclear } \\
\text { cells from healthy and grass } \\
\text { pollen allergic subjects }\end{array}$ & $\begin{array}{l}\text { TH1 switch (IL4/IFN } \gamma \\
\text { ratio); } \\
\oplus \text { IL10, IL12; } \downarrow \text { CD23 }\end{array}$ & $\begin{array}{l}\text { Rasche et al. } \\
2007\end{array}$ \\
\hline
\end{tabular}


Table 1 continued

\begin{tabular}{|c|c|c|c|c|c|}
\hline Probiotic microorganism & $\begin{array}{l}\text { Inactivation } \\
\text { treatment }\end{array}$ & $\begin{array}{l}\text { Bacterial } \\
\text { component(s) }\end{array}$ & Type study & Immune response elicited & References \\
\hline Bacillus coagulans GBI-30 & 1 & $\begin{array}{l}\text { Cell wall } \\
\text { components }\end{array}$ & $\begin{array}{l}\text { Human polymorphonuclear } \\
\text { cells }\end{array}$ & $\begin{array}{l}\oplus \text { IL-4, IL-6, IL-10; } \\
\downarrow \text { ROS, IL-2; } \\
\downarrow \text { Chemotactic migration in } \\
\text { response to IL-8 and } \\
\text { leukotriene B4 }\end{array}$ & $\begin{array}{l}\text { Jensen et al. } \\
2010\end{array}$ \\
\hline Lactobacillus casei Shirota & I & $\begin{array}{l}\text { Insoluble intact } \\
\text { cell wall }\end{array}$ & Mouse peritoneal macrophages & $\oplus \mathrm{IL}-12$ & $\begin{array}{l}\text { Shida et al. } \\
2006\end{array}$ \\
\hline $\begin{array}{l}\text { L. plantarum K8 } \\
\text { (KCTC10887BP) }\end{array}$ & l & LTAs & Human monocytic THP-1 cells & $\begin{array}{l}\text { Downregulation of NOD2 } \\
\text { expression induced by } \\
\text { PGN of Shigella flexneri } \\
\text { KCTC } 2517\end{array}$ & $\begin{array}{l}\text { Kim et al. } \\
2011\end{array}$ \\
\hline $\begin{array}{l}\text { L. johnsonii La1 } \\
\text { L. acidophilus La10 }\end{array}$ & I & LTAs & Human HT29 cell line & $\begin{array}{l}\text { Inhibition of LPS } \\
\text { responsiveness mediated } \\
\text { by soluble CD14 }\end{array}$ & $\begin{array}{l}\text { Vidal et al. } \\
2002\end{array}$ \\
\hline $\begin{array}{l}\text { L. casei YIT } 9029 \\
\text { L. fermentum YIT } 0159 \\
\text { (FERM P-13859) }\end{array}$ & I & LTAs & $\begin{array}{l}\text { Mouse RAW264.7 } \\
\text { macrophages }\end{array}$ & $\begin{array}{l}\oplus \text { TNF- } \alpha \text { through NF- } \kappa \mathrm{B} \\
\text { activation }\end{array}$ & $\begin{array}{l}\text { Matsuguchi } \\
\text { et al. } 2003\end{array}$ \\
\hline L. plantarum ATCC $14917^{\mathrm{T}}$ & & WTAs & $\begin{array}{l}\text { Mouse leukaemic monocyte } \\
\text { macrophage cell line }\end{array}$ & $\begin{array}{l}\text { Activation of ERK, } \oplus \\
\text { IL-10; } \\
\downarrow \text { IL-12 }\end{array}$ & $\begin{array}{l}\text { Kaji et al. } \\
2010\end{array}$ \\
\hline L. acidophilus NCFM & l & SlpA & $\begin{array}{l}\text { Immature human dendritic } \\
\text { cells }\end{array}$ & $\begin{array}{l}\oplus \text { IL-10 expression through } \\
\text { DC-SIGN in the presence } \\
\text { of LPS; activation of IL-4- } \\
\text { producing T cells }\end{array}$ & $\begin{array}{c}\text { Konstantinov } \\
\text { et al. } 2008\end{array}$ \\
\hline $\begin{array}{l}\text { L. johnsonii La1 (NCC 533) } \\
\text { L. helveticus ATCC15009, } \\
\text { Bacillus subtilis NCC199 } \\
\text { Lactococcus lactis MG }\end{array}$ & l & GroEL & $\begin{array}{l}\text { Human HT29 cells and } \\
\text { macrophages }\end{array}$ & $\oplus$ IL-8 & $\begin{array}{l}\text { Bergonzelli } \\
\text { et al. } 2006\end{array}$ \\
\hline $\begin{array}{l}\text { Bifidobacterium bifidum } \\
\text { MIMBb75 }\end{array}$ & l & BopA & Human Caco-2 cell line & $\oplus \mathrm{IL}-8$ & $\begin{array}{r}\text { Guglielmetti } \\
\text { et al. } 2008\end{array}$ \\
\hline $\begin{array}{l}\text { Bifidobacterium breve, } \\
\text { Bifidobacterium longum } \\
\text { subsp. longum and } \\
\text { Bifidobacterium longum } \\
\text { subsp. infantis }\end{array}$ & l & Genomic DNA & $\begin{array}{l}\text { Human peripheral blood } \\
\text { mononuclear cells }\end{array}$ & $\begin{array}{l}\oplus \mathrm{IL}-10 ; \\
\downarrow \mathrm{IL}-1 \beta\end{array}$ & $\begin{array}{l}\text { Lammers } \\
\text { et al. } 2003\end{array}$ \\
\hline
\end{tabular}

In vivo studies are indicated. Where not indicated, the study has been performed in vitro. $W B C$ whole bacterial cells have been used. $\oplus$, enhanced production; $\downarrow$, inhibited production

$D C$-SIGN dendritic cell-specific intercellular adhesion molecule-3-grabbing non-integrin, Der $p 2$ a major allergen from dermatophagoides pteronyssinus, $E R K$ extracellular-signal-regulated kinase, $I F N-\gamma$ interferon- $\gamma, I g$ immunoglobulin, $I L$ interleukin, $L P S$ lipopolysaccharide from Escherichia coli, LTAs lipoteichoic acids, $N F-\kappa B$ nuclear factor kappa-light-chain-enhancer of activated B cells, $N O$ nitric oxide, $N O D 2$ nucleotide-binding oligomerisation domain containing, $O V A$ ovalbumin, ROS reactive oxygen species, Slp surface layer protein, TAs teichoic acids, TGF- $\beta$ transforming growth factor $\beta, T N F-\alpha$ tumour necrosis factor- $\alpha$, WTAs wall teichoic acids

strains, $\mathrm{Bb} 1$ and $\mathrm{Bb} 2$, enhanced the production of the cytokines, IL-12, interferon (IFN)- $\gamma$, TNF- $\alpha$ and IL-10, whereas IL-13 was reduced when these strains were incubated with stimulated peripheral blood mononuclear cells (PBMCs), similar to the results obtained by using live bacteria. The latter study suggests that probiotics can induce a $\mathrm{T}$ helper 1 and/or regulatory phenotype when cultured with activated PBMCs, and very importantly, they maintain this ability even after inactivation (Tejada-Simon and Pestka 1999).

An experiment performed on the human epithelial colorectal adenocarcinoma Caco- 2 cell line demonstrated that both viable and UV-inactivated LGG cells exerted the same effects, namely, the reduction in the proinflammatory cytokine, IL-8, upon flagellin induction (Lopez et al. 2008). In a previous report by the same authors (Zhang et al. 
2005), an identical LGG strain was inactivated with heat treatment and used in experiments with Caco- 2 cells. They observed that although pretreatment with both viable and inactivated LGG cells was effective in downregulating the inflammatory response induced by $\mathrm{TNF}-\alpha$, the highest tested dose of the live agent without pre-existing inflammatory stimulation actually caused a large increase in IL-8 production, whereas this effect was minimal with the heatkilled form. In the light of these data, it could be suggested that under certain conditions, heat-killed bacteria may represent a safer alternative (Kataria et al. 2009).

It is plausible to propose that when different responses are triggered by viable and inactivated cells, the mechanism of action is different, and different signalling cascades may be activated. However, it has also been observed that even when viable and inactivated cells trigger the same immune response, there could be different underlying mechanisms of action. Accordingly, Lopez et al. (2008) demonstrated that UV-inactivated and live LGG were equally effective at decreasing IL-8 production in Caco-2 cells by altering the inhibitor protein of nuclear factor (NF)- $\kappa \mathrm{B}$ namely $\mathrm{I} \kappa \mathrm{B}$, thereby impeding NF- $\kappa \mathrm{B}$ translocation. Surprisingly, they found that only UV-inactivated LGG decreased the levels of the ubiquitinated inhibitor $-\kappa \mathrm{B}$ (Ub-I $\kappa \mathrm{B}$ ), whereas live LGG did not affect Ub-I $\kappa \mathrm{B}$. Therefore, although both live and UV-inactivated LGG altered cytoplasmic $\mathrm{I} \kappa \mathrm{B}$, thereby inhibiting NF- $\kappa \mathrm{B}$ nuclear translocation, the mechanism proceeded along different pathways (Lopez et al. 2008).

The scientific literature presented thus far suggests that loss of viability of probiotic microorganisms can induce further and more complex effects than expected, in terms of immunomodulation.

\section{The ability of inactivated probiotics to mediate the Th1/ Th2 switch: potential role in allergy management}

The balance of $\mathrm{T}$ helper (Th) cell populations is believed to be important for the maintenance of homeostasis in the host. Th1 cytokines, such as IL-2 and TNF- $\alpha$, augment cellular immunity, whereas Th2 cytokines, such as IL-4 and IL-13, enhance humoral immunity (Fedorak and Madsen 2004b; Sartor 2005). Once this balance becomes disturbed, various immunological diseases, such as allergies and infections, can occur through the evasion of host defence mechanisms.

In recent years, the beneficial effects of probiotics on immune-mediated diseases, such as allergies and asthma, have been documented (Di Giacinto et al. 2005). One explanation for the beneficial effect of probiotics on allergic responses is their inhibition of the production of IgE (Majamaa and Isolauri 1997). Furthermore, many studies have proposed that probiotics, even as inactivated cells, are able to turn a Th2 response into a Th1 or Th0/ Treg response. A brief review of in vivo and ex vivo studies concerning the usefulness of inactivated probiotics in allergy management is presented below.

Recently, an in vivo study revealed the immunomodulatory activity of inactivated probiotic cells from VSL\#3, a commercial probiotic mixture that contains eight different bacterial strains (four lactobacilli, three bifidobacteria and one Streptococcus thermophilus strain), which was demonstrated to be beneficial in treating inflammatory bowel diseases (Bibiloni et al. 2005). In the study by Mastrangeli et al. (2009), both live and sonicated VSL\#3 preparations were shown to modulate cytokine production by splenocytes in mice sensitised with Par $\mathrm{j} 1$ (the predominant allergen protein from the pollen of Parietaria judaica) towards a Treg/Th0 profile characterised by increased IL-10 and IFN- $\gamma$ production. In addition, prophylactic treatment of mice by intranasal administration of sonicated VSL\#3 cells before immunisation with recombinant Par $\mathrm{j}$ induced a significant reduction in serum antigen-specific IgG1, markedly reduced IL-13 and IL-4 mRNA and increased IL-10 expression in the lungs. Therefore, inactivated VSL\#3 preparations not only had the capacity to bias primary immune responses towards a Treg/Th0-type profile but also to modulate the development of Th2-biased responses. It is interesting that the predetermined properties of a probiotic product that is already on the market are maintained after inactivation of its probiotic cells.

In the case of a mixture of different bacterial strains from diverse genera, such as VSL\#3, it is possible that different microbial strains exert diverse effects, as suggested by Hart et al. (2004). This study found that cell wall fractions from the individual strains of VSL\#3 had distinct immunomodulatory effects on dendritic cells. The most marked anti-inflammatory effects were produced by bifidobacteria, which upregulated IL-10 production by dendritic cells in a dose-dependent manner and decreased IFN- $\gamma$ production by $\mathrm{T}$ cells. Bifidobacteria also reduced the expression of the costimulatory molecule, cluster of differentiation 80 (CD80), a protein present on activated $\mathrm{B}$ cells and monocytes that provides a costimulatory signal necessary for T-cell activation and survival. Moreover, cell envelope components of $B$. breve and $B$. infantis reduced the level of CD40 expression on dendritic cells (DCs). Signalling through CD40 increases IL-12 production by DCs and enhances their survival (Björck et al. 1997; Cella et al. 1996); in addition, increased levels of CD40 expression have been demonstrated to be important in mucosal inflammation (Stagg et al. 2000). In contrast, cell wall preparations from VSL\#3 lactobacilli decreased or failed to affect the production of IL-10 by DCs. Thus, 
unlike bifidobacteria, lactobacilli appear to generate "semi-mature", DCs (Lutz and Schuler 2002), a phenotype characterised by increased costimulatory marker expression but low production of proinflammatory cytokines. As described previously, "semi-mature", DCs have been shown to contribute to the induction of regulatory $\mathrm{T}$ cells and subsequent tolerance in vivo (Lutz and Schuler 2002). These data support the idea that synergistic effects between different probiotic strains can enhance or modify immunomodulatory effects compared with a single bacterial strain.

Several other groups have reported that inactivated lactobacilli can induce a switch of $\mathrm{T}$ helper response towards a Th1 phenotype. For instance, in a study by Chuang et al. (2007), three different strains of Lactobacillus, including L. acidophilus A2, L. gasseri A5 and L. salivarius A6, were tested on mouse splenocytes after heat inactivation to evaluate proliferation and cytokine profiles. The bacterial preparations induced the proliferation of splenocytes and the production of IL-10, IL-12p70 and IFN- $\gamma$. The three heat-killed Lactobacillus strains were also tested on bone marrow-derived dendritic cells from $\mathrm{BALB} / \mathrm{c}$ mice, and these strains were found to induce high levels of IL-12p70, but the levels of IL-4 and IL-10 were lower and unchanged, respectively, compared with controls (Chuang et al. 2007).

In other studies, inactivated Lactobacillus cells induced a decrease in the production of IgE. As an example, when BALB/c mice were fed heat-killed L. casei Shirota and subsequently immunised by intraperitoneal injection of ovalbumin (OVA), Matsuzaki and Chin found that mice had significantly reduced levels of OVA-specific $\operatorname{IgE}$ compared to the untreated controls (Matsuzaki and Chin 2000). In addition, in mice that had been fed inactivated Shirota cells, the levels of Th1-associated cytokines, such as IFN- $\gamma$ and IL-2, produced by splenocytes were higher than in the control group, whereas the production of Th2associated cytokines, such as IL-4, IL-5 and IL-6, was lower. These results indicate that inactivated $L$. casei Shirota cells inhibited Th2 cells, thereby reducing the production of $\mathrm{IgE}$.

In another mouse allergy model, the properties of L. casei Shirota were tested under Th2 differentiation conditions. C57BL/6 mice were presensitised by epicutaneous patching with recombinant Der $\mathrm{p}$ 2, a major allergen from Dermatophagoides pteronyssinus (the main species of house dust mite and a major inducer of asthma), and orally alimented with heat-killed wild-type Shirota cells (Lim et al. 2009). Der p 2-sensitised mice fed with inactivated Shirota showed significantly lower Der p 2-specific IgE and IgG1 after subcutaneous immunisation and airway challenge with Der p 2 compared with the untreated group. Moreover, splenic $\mathrm{T}$ cells of Shirota-fed mice showed suppression of Th-2 (IL-5, IL-13 and IL-4) and proinflammatory (TNF- $\alpha$, IFN- $\gamma$ ) cytokines, whereas in the case of airway allergen challenge, Shirota-fed mice had histological evidence of reduced lung inflammation as well as decreased proinflammatory cytokines in bronchoalveolar lavage fluid. Consequently, the authors proposed the use of inactivated L. casei Shirota cells as an intrinsic adjuvant for secondary prevention or treatment of allergic respiratory diseases (Lim et al. 2009).

Lactobacilli have also been shown to be 'protective' against a Th2 response in the context of food allergy. Heatkilled Lactobacillus plantarum L-137, for instance, was administered intraperitoneally to DBA/2 mice fed a casein diet (Murosaki et al. 1998). It was previously observed from in vitro analyses that inactivated L-137 directly induced IL-12 production by peritoneal macrophages and stimulated spleen cells to produce both IL-12 and IFN- $\gamma$. Furthermore, in vivo experiments demonstrated an increase in plasma levels of IL-12 and significant suppression of casein-specific $\operatorname{IgE}$ in $\mathrm{DBA} / 2$ mice fed a casein diet and injected with killed L-137. These data suggest that inactivated L. plantarum L-137 cells are potent inducers of IL-12 in macrophages both in vitro and in vivo and could be useful as a therapeutic or prophylactic agent to control food allergies.

The ability of certain lactobacilli strains to induce IL-12 is of particular interest, since this cytokine has been shown to inhibit IL-4-induced IgE synthesis in vitro (Kiniwa et al. 1992) and suppress anti-IgD-induced IgE production in vivo (Morris et al. 1994); furthermore, the presence of IL12 during initial antigen presentation has been shown to inhibit Th2 responses (Manetti et al. 1994). It has also been suggested that IL-12 released from macrophages is the primary cause of the biological effects of lactobacilli on IFN- $\gamma$ production and augmentation of natural killer cell activity (de Simone et al. 1986; Muscettola et al. 1994).

The effects of oral administration of heat-killed Lactobacillus acidophilus L-92 on BALB/c mice following OVA immunisation revealed a significant reduction in OVAspecific IgE. In addition, analysis of splenocytes collected from immunised mice confirmed that inactivated L-92 cells increased IFN- $\gamma$ and reduced Th2 cytokines (Torii et al. 2007). Further analyses were then performed to investigate how oral administration of inactivated L-92 cells affected gut immunity in mice using cells from Peyer's patches (PPs). It has been proposed that orally administered lactic acid bacteria (LAB) are initially incorporated into $M$ cells, likely interacting via Toll-like receptor (TLR) 2 (TLR2 has been suggested to mediate transcytosis and transport of LAB; Tohno et al. 2005). LAB are then transferred to PPs, which play a leading role in gut immunity by stimulating DCs. Experiments on killed L-92 cells showed a significant increase in TGF- $\beta$ and total IgA in PP cells. On the basis of 
these results, it seems possible that the suppression of $\mathrm{IgE}$ production by this Lactobacillus strain proceeds through a mechanism that does not involve a shift to Th1-dominant immunity. TGF- $\beta$ is associated with activation of regulatory $\mathrm{T}$ (Treg) cells. Therefore, L-92 might induce Th3 regulatory cells, which subsequently migrate throughout the body and modulate the Th1/Th2 balance. It has also been shown that TGF- $\beta$, secreted from DCs within PPs, induces oral tolerance through induction of Treg cells (Weiner 2001a; Weiner 2001b) as already proposed for lactobacilli by Smits et al., who assessed the mechanism of Treg cell activation in human DCs using lactobacilli of different species (Smits et al. 2005).

In 2007, Rasche and collaborators published the results of an ex vivo study where they described the effects of a probiotic Lactobacillus acidophilus strain and E. coli Nissle 1917 strain on the phenotype and function of $\mathrm{T}$ and B cells from allergic and healthy subjects. PBMCs were extracted from sensitised allergic individuals and healthy controls, and it was found that costimulation with grass pollen allergen in the presence of low-temperature-inactivated bacterial cells from both strains switched the immune response from a Th2-dominated response to a Th1-dominated response as determined by the IL-4/IFN $\gamma$ ratio. This result was true especially for $E$. coli, which, unlike Lactobacillus, also enhanced the production of IL-10 and IL-12. Moreover, allergic patients showed decreased expression of CD23 in the presence of bacteria and especially in the presence of $E$. coli Nissle. CD23 is an important receptor involved in the regulation of $\operatorname{IgE}$ and plays a crucial role in regulating $\mathrm{T}$ - and $\mathrm{B}$-cell interactions during the allergic response (Corominas et al. 1998). Accordingly, the same authors observed an increase in expression of CD23 in patients suffering from atopic dermatitis and allergic rhinitis (Frotscher et al. 2002). Once activated, CD23 becomes a soluble factor and migrates into the blood where it induces the recruitment of non-sensitised B cells and the presentation of peptides to allergen-specific B cells, thereby increasing the production of allergen-specific IgE. These observations, as suggested by the authors, are closely related to the modulating effects of IL-4 and IFN $\gamma$ on CD23 expression. A previous study described an increased level of CD23 expression that was related to IL-4 production and a reduction in both $\mathrm{CD} 23 \mathrm{mRNA}$ and $\mathrm{sCD} 23$ production in human $\mathrm{B}$ cells as a result of IFN $\gamma$ expression (Corominas et al. 1998). These studies indicate that the bioactive compounds from non-viable L. acidophilus and E. coli modulate the Th2-like response characterised by enhanced IL-4 production and upregulation of CD23 on B lymphocytes in allergic individuals. The shift in the Th1/Th2 balance as assessed by IL- 4 and IFN $\gamma$ supports the idea of a therapeutic potential for inactivated probiotic cells in the management of allergic disease. On the contrary, the promotion of Th1-dominated immune responses by long-term administration of bacteria, especially E. coli, may be problematic, as autoimmune diseases are characterised by high levels of Th1 cytokines (Rasche et al. 2007). In the light of the possible impact on host immunity, it would be preferable to select potential probiotic strains to promote a Th0/Treg profile.

\section{What is keeping bacteria immunologically effective after inactivation? Possible mechanisms of action}

The discovery of a clear potential to exert beneficial immunological effects using inactivated bacteria suggests that further investigation into their mechanisms of action is required. Several mechanistic studies have demonstrated that specific chemical compounds isolated from bacteria can induce specific immune responses (Fig. 1). These investigations provide the scientific basis for a molecular explanation of the immunological effects observed in vivo after administration of inactivated probiotic bacteria or probiotic cell extracts. Excluding extracellular bacterial products, a major role in immunomodulatory activity should be mediated by the structural components of the cell, particularly the cell envelope, the outermost structure that immune system cells come into contact with first, which includes cell wall constituents or, if they are present, S-layer proteins, capsule and pellicle (Chapot-Chartier et al. 2010). Nevertheless, attention should be given to every possible bacterial cell component as suggested by Tejada-Simon and Pestka (1999). In this study, RAW 264.7 macrophages were exposed to heat-killed Bifidobacterium sp., Lactobacillus acidophilus, Lactobacillus bulgaricus, Lactobacillus casei, Lactobacillus gasseri, Lactobacillus helveticus, Lactobacillus reuteri and Streptococcus thermophilus as well as the cell envelope components and cytoplasmic extracts of these bacteria. Whole inactivated cells, the cell envelope components and cytoplasmic fractions from probiotic bacteria stimulated macrophages to produce TNF- $\alpha$, IL-6 and nitric oxide, suggesting that bioactive compounds are potentially located everywhere in the bacterial cells. More recently, it was shown that cell wall components isolated from the probiotic spore-forming bacterium, Bacillus coagulans GBI-30, had inhibitory activity in several bioassays involving pro-inflammatory immune responses (Jensen et al. 2010). These responses included the inhibition of reactive oxygen species (ROS), reduced polymorphonuclear (PMN) cell chemotactic migration in response to IL-8 and leukotriene $\mathrm{B} 4$, the production of the Th2 cytokines (IL-4, IL-6 and IL-10) and the inhibition of IL-2 (Jensen et al. 2010). 


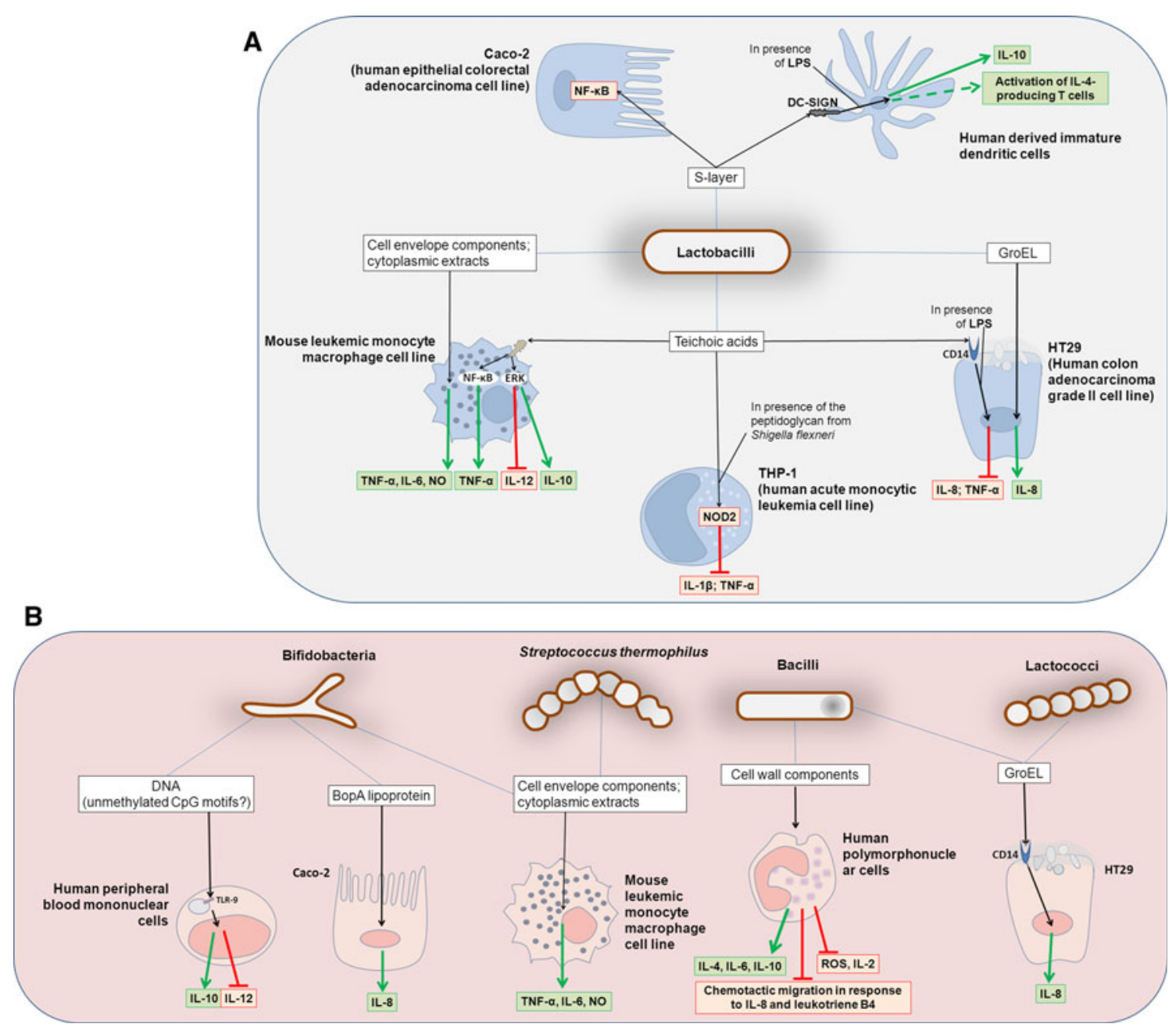

Fig. 1 Interaction between host immune system and cellular components of probiotic bacteria. a Molecules or fractions from Lactobacillus cells demonstrated to activate host immune and epithelial cells. b Immunomodulatory molecules or fractions isolated from other probiotic bacterial cells. Cytokines, immunological activities or cell factors that have been inhibited are indicated in a red rectangle, while those that have been enhanced are in a green rectangle. The immunomodulatory activities shown in the picture have been experimentally proven only for certain strains/species inside a bacterial group: consult the references cited in the article for more details. GroEL is a chaperone protein (heat-shock protein) found

\section{Bacterial cell wall components}

The immunological effects of bacterial cell envelope components are not surprising, considering the literature briefly discussed below and the immunomodulatory properties attributed to specific molecular cell wall components. Peptidoglycan (PGN) and lipopolysaccharide (LPS, also known as bacterial endotoxin) are well-known potent activators of immune responses. PGN is the main constituent of Gram-positive bacterial cell walls, accounting for up to $90 \%$ of their weight, whereas it constitutes only $15-20 \%$ of the cell wall in Gram-negative bacteria (Warshakoon et al. in many bacteria; BopA is a cell surface lipoprotein identified in Bifidobacterium bifidum, which has been demonstrated to promote the adhesion of the bacterium on Caco-2 cells. DC-SIGN dendritic cellspecific intercellular adhesion molecule-3-grabbing non-integrin, $E R K$ extracellular-signal-regulated kinase, $I L$ interleukin, $L P S$ lipopolysaccharide from Escherichia coli, $N F-\kappa B$ nuclear factor kappalight-chain-enhancer of activated $\mathrm{B}$ cells, $N O$ nitric oxide, $N O D 2$ nucleotide-binding oligomerisation domain containing, $R O S$ reactive oxygen species, TLR Toll-like receptor, $T N F-\alpha$ tumour necrosis factor- $\alpha$

2009). A thick PGN layer is generally the outermost structure covering Gram-positive cells, whereas in Gramnegative bacteria, there is an outer biological membrane that contains around 13\% LPS and exposes the LPS-core polysaccharides and LPS-O-antigens to the external environment. Numerous studies conducted on PGN and LPS isolated from pathogenic bacteria have demonstrated that both types of molecules stimulate the immune system through a receptor-dependent process involving the host cell-surface protein, CD14. Specialised conserved pattern recognition receptors (PRRs) on host cell membranes, such as TLRs and the nucleotide-binding domain (NOD) proteins 
(or NOD-like receptors, NLRs), are the primary sensors of the innate immune system and recognise microbe-associated molecular patterns, including PGN and LPS. In particular, TLR4 is a specialised receptor for LPS, whereas both NOD1 and NOD2 recognise muramylpeptides released from PGN, although each detects distinct motifs within this structure (Philpott and Girardin 2004).

PGN and LPS have traditionally been considered molecules that promote adverse events, such as fever, arthritis and auto-immune diseases (Marteau and Shanahan 2003; Nahra and Dellinger 2008; Opal 2010). Nonetheless, the composition of PGN and LPS differs largely from one bacterium to another, and even small chemical modifications can yield significantly different immunological consequences (Lebeer et al. 2010). For instance, the PGN from Gram-negative and Gram-positive bacteria differs in thickness, degree of stem peptide cross-linking and nature of the third amino acid of the stem peptides (diaminopimelic acid, DAP, instead of lysine in Gram-negative bacteria). These differences can be sensed by host PRRs, as shown for NOD1, which specifically detects the presence of meso-DAP in PGN, a signature of Gram-negative bacteria (Girardin et al. 2003).

Another example is the LPS molecule in E. coli Nissle 1917 (DSM 6601), the only Gram-negative probiotic bacterium that is commercially available in Europe and has been included in a wide number of clinical trials and laboratory studies (Trebichavsky et al. 2010). A 2002 study demonstrated that in $E$. coli Nissle 1917 (serotype O6:K5:H1), a single mutation caused by a nucleotide substitution truncated the gene for the O-antigen polymerase, Wzy, which catalyses the polymerisation of the $\mathrm{O}$ LPS subunits into a long-chain polysaccharide. The resulting modified chemical composition of LPS in E. coli Nissle showed a decreased ability to withstand the antibacterial defence mechanisms in the blood, contributing to the very low pathogenic potential of this Gram-negative probiotic strain (Grozdanov et al. 2002).

In Gram-positive bacterial cell walls, there are molecules protruding from the external surface of the PGN layer known as teichoic acids (TAs). TAs are phosphodiester polymers of glycerol or ribitol, and they can be covalently linked to either peptidoglycan (wall teichoic acids, WTAs) or the cytoplasmic membrane (lipoteichoic acids, LTAs). Several studies have demonstrated the involvement of TAs in immune responses. With respect to microorganisms of probiotic interest, TAs from lactobacilli have been proposed to elicit proinflammatory responses through TLR2. Indeed, LTAs purified from L. casei YIT 9029 and $L$. fermentum YIT 0159 (FERM P-13859) were demonstrated to induce elevated levels of TNF- $\alpha$ in mouse RAW264.7 macrophages through $\mathrm{NF}-\kappa \mathrm{B}$ activation mediated by TLR2, but not TLR4 (Matsuguchi et al. 2003).
It has also been proposed that Gram-positive probiotic and commensal intestinal bacteria temper the immune response to microorganisms in the intestine via their TAs, preventing an exaggerated inflammatory response (Vidal et al. 2002). This hypothesis has been supported by the observation that LTAs from Lactobacillus johnsonii La1 and Lactobacillus acidophilus La10 inhibit the LPS responsiveness mediated by soluble CD14 in the HT29 human intestinal epithelial cell line (Vidal et al. 2002).

More recently, it has been shown that $L$. plantarum ATCC $14917^{\mathrm{T}}$ potently activates the extracellular-signalregulated protein kinase (ERK) pathway via TLR2mediated recognition of WTAs, inducing potent IL-10 production with a simultaneous reduction in IL-12 (Kaji et al. 2010).

Finally, a study carried out on human monocytic THP-1 cells has revealed that LTAs purified from L. plantarum K8 (KCTC10887BP) are potent modulators of the proinflammatory NOD2-related signalling pathway triggered by the PGN of Shigella flexneri KCTC 2517, as demonstrated by downregulation of NOD2 expression at the mRNA and protein levels. In this study, LTAs purified from the L. plantarum K8 strain induced cross-tolerance and inhibited excessive inflammatory responses induced by the pathogenic components (Kim et al. 2011).

At the end of this short discussion on the immunomodulatory properties attributed to cell wall constitutive macromolecules, it appears however of importance mentioning that the contamination of cell wall preparations by other cell envelope components can be hardly avoided and monitored. Such contaminations, therefore, could have potentially contributed to the observed immunological results.

\section{Other bacterial molecules}

Probiotic lactobacilli may also engage in cross-talk with the host immune system by means of their surface layer (S-layer), a monomolecular crystalline envelope produced by the self-assembly of protein or glycoprotein subunits on the outer cell surface. S-layers are commonly found in prokaryotes and can represent up to $10-15 \%$ of the total protein content of a cell (Avall-Jääskeläinen and Palva 2005). The commercial probiotic Lactobacillus acidophilus NCFM strain possesses an S-layer primarily composed of a 45-kDa protein named SlpA. Konstantinov et al. (2008) demonstrated that NCFM SlpA was recognised and bound by DC-SIGN (dendritic cell-specific intercellular adhesion molecule-3-grabbing non-integrin, also known as CD209), a C-type lectin receptor presents on both macrophages and dendritic cells. Notably, they found that NCFM-expressing SlpA was captured by DC-SIGN on DCs, resulting in an interaction that appeared to be crucial for the activation of 
IL-4-producing T cells; in contrast, a knockout mutant of L. acidophilus NCFM lacking SlpA demonstrated significantly impaired binding to DC-SIGN (Konstantinov et al. 2008). These data were confirmed by experiments performed with purified SlpA protein, which ligated to DC-SIGN and induced IL-10 expression by DCs in the presence of LPS (Konstantinov et al. 2008).

A homologous Slp protein is also present in Lactobacillus helveticus strains, and it appears to mediate an immunological effect for members of this species as well. For instance, SlpA from L. helveticus MIMLh5, a bacterium demonstrated to interact with host cells and modulate immune responses (Guglielmetti et al. 2010), markedly altered cytokine production through the inhibition of NF$\kappa \mathrm{B}$ activation in human intestinal epithelial cells (Taverniti and Guglielmetti, manuscript in preparation).

Other proteins associated with probiotic bacteria have been shown to elicit immune responses. For example, the heat-shock protein GroEL (Hsp60 class), of L. johnsonii La1 (NCC 533), which is also present at the cell surface, was expressed in E. coli, and its purified recombinant form (rGroEL) was shown to bind to mucins and epithelial cells, stimulating IL-8 secretion in macrophages and HT29 cells in a CD14-dependent manner (Bergonzelli et al. 2006). This property was also observed in rGroEL from three other Gram-positive bacteria, including $L$. helveticus ATCC15009, Bacillus subtilis NCC199 and Lactococcus lactis MG, but not in the rGroEL of the gastric pathogen, H. pylori P1 (Bergonzelli et al. 2006).

Another example is BopA, a cell surface-associated lipoprotein of Bifidobacterium bifidum MIMBb75 that mediates adhesion to human Caco-2 intestinal epithelial cells. Upon purification from strain MIMBb75, BopA has been demonstrated to induce the production of IL-8 by Caco- 2 cells in a dose-dependent manner (Guglielmetti et al. 2008).

Finally, probiotics can interact with the host immune system by means of their genomic DNA. Convincing scientific evidence has shown that prokaryotic DNA contains unmethylated $\mathrm{CpG}$ motifs that can activate immune responses in vitro and in vivo (Agrawal and Kandimalla 2002; Rachmilewitz et al. 2002). Lammers et al. (2003) observed that bacterial genomic DNA extracted from pure bifidobacterial cultures of the probiotic commercial product, VSL\#3 (including B. breve, B. longum subsp. longum and B. longum subsp. infantis), influenced cytokine production by peripheral blood mononuclear cells (PBMCs), decreasing IL-1 $\beta$ and increasing IL-10. The anti-inflammatory effect of genomic DNA from VSL\#3 bacteria was also confirmed in an in vivo murine study, which demonstrated that TLR9 signalling was essential in mediating this anti-inflammatory effect (Rachmilewitz et al. 2004). It has been suggested that the immunological effect observed with bifidobacterial genomic DNA is favoured by the high guanine-cytosine (GC) content of the Bifidobacterium genus $(58-61 \%)$, which explains the redundancy of different $\mathrm{CpG}$ motifs in the genomes of these bacteria (Lammers et al. 2003).

In a more recent study, Medina et al. (2007) detected a large variation in the ability of seven different strains of the same Bifidobacterium species (B. longum) to modulate the in vitro production of cytokines by PBMCs, suggesting the importance of careful strain selection before any specific use. The authors also proposed that the differential effects exerted by B. longum strains could be due to differences in the presence or redundancy of $\mathrm{CpG}$ motifs in their genomes. These variations, in fact, can induce a more or less pronounced immunomodulatory effect (Yi et al. 2002). In addition, genome comparison is revealing that Bifidobacterium strains may encode different restriction/modification systems (O'Connell Motherway et al. 2009; Lee and O'Sullivan 2010), which in turn lead to differences in their DNA methylation profiles and, possibly, immune responses. It should be, finally, taken into consideration that the purification of DNA from bacterial cultures is a challenging task, particularly due to the contamination by exopolysaccharides (EPS), such as those known to be often produced by bifidobacteria (Ruas-Madiedo et al. 2007). Since variation in such EPS molecules is substantial and strain dependent, the actual immunological differences may be potentially due to EPS rather than DNA.

Despite the high-quality research performed up to now, we are still far from an exhaustive explanation of the biological effects observed after administration of nonviable probiotics. Mechanistic reductionist approaches, such as those employed in the studies described here, are not sufficient to unveil all the potential properties of inactivated bacteria or bacterial cell extracts. A single molecule, in fact, can display different effects if studied alone or in a complex multicomponent context (Kaji et al. 2010). The potential bioactivity of a specific bacterial compound can be masked by other cell structures, and the effects of a single molecule can be influenced by the presence of additional bioactive substances. In support of this concept, a recent study by Kaji and collaborators (Kaji et al. 2010) identified TAs as key factors for triggering the synergistic induction of IL-10 production; they demonstrated that TAs alone only weakly induced IL-10 production, but when macrophages sensed WTAs or LTAs in the presence of $L$. casei strain Shirota, these stimuli cooperatively induced potent production of IL-10 (Kaji et al. 2010).

Another investigation showed that the whole bacterial cell wall was necessary to trigger an immunological response. Shida and colleagues observed that the insoluble intact cell wall of the probiotic strain, L. casei Shirota, was 
necessary in stimulating macrophages to produce IL-12, since this ability was lost when only the soluble polysaccharide-peptidoglycan complex released from the cell wall was tested (Shida et al. 2006).

In a different study, Ryan et al. (2009) separated the cell envelope from the cytoplasmic fraction of $L$. salivarius UCC118, a strain that was demonstrated independently of its viability to decrease IL- 8 production by gastric epithelial cells upon exposure to $H$. pylori cells. However, when they tested the two fractions separately, neither was able to retain any statistically significant anti-IL-8 activity, suggesting that intact cells, either alive or killed, were required (Ryan et al. 2009).

\section{Conclusions}

A considerable amount of published data, some of which have been reported here and in other review articles (Adams 2010; Kataria et al. 2009), indicates that the use of non-viable microbial cells or cell components can influence host's immune system. The emerging concern regarding potential safety problems arising from the extensive use of live microbial cells has been dramatically validated by Besselink's communication on the effects of probiotics in acute pancreatitis (Besselink et al. 2008). These concerns have enhanced the interest in non-viable microorganisms or microbial cell extracts, as they could drastically reduce shelf-life problems and eliminate the risks of microbial translocation and infection for the consumer (Cross et al. 2004).

In the last fifteen years, several definitions of probiotic have been proposed, some of them even comprising nonviable microbial cells. For instance, Reuter (1997) described probiotics as 'a microbial preparation which contains live and/or dead cells including their metabolites which is intended to improve the microbial or enzymatic balance at mucosal surfaces or to stimulate immune mechanisms'. Similarly, Salminen et al. (1999) spoke about probiotics as 'microbial cell preparations or components of microbial cells that have a beneficial effect on the health and wellbeing of the host'. Despite the potential legitimacy of these definitions, nowadays, at least in Western Countries, the definition of probiotics nearly unanimously accepted is that by FAO/WHO ('live microorganisms which when administered in adequate amounts confer a health benefit on the host'). Accordingly, national/government institutions are introducing the FAO/WHO definition in their guidelines for probiotics. For instance, this definition is proposed in the guidelines of Italian Ministry of Health (Ministero della Salute 2005), in a dossier from French Agency for Food Safety, (Agence Française de Sécurité Sanitaire des Aliments 2005) and in the guidance document on the use of probiotics in food by the Department for Public Health of Canada (Health Canada 2009). Thereby, use of the word 'probiotic' should be restricted to products that contain live microorganisms; consequently, we now require new terminology to unambiguously define the use of non-viable microorganisms or microbial fractions to positively affect health. To this end, we propose the use of the term 'paraprobiotic' (or 'ghost probiotics'), to be defined as 'non-viable microbial cells (intact or broken) or crude cell extracts (i.e. with complex chemical composition), which, when administered (orally or topically) in adequate amounts, confer a benefit on the human or animal consumer'. The prefix 'para' (from the ancient Greek, $\pi \alpha \rho \dot{\alpha}$ ) has been chosen because of its meaning of 'alongside of' or 'atypical', which can simultaneously indicate similarity to and difference from the traditional probiotic definition. Purified molecules of microbial origin or pure microbial cell products are omitted from the concept of paraprobiotics, since their use should be included in conventional pharmaceutical methodologies. In addition, once a health benefit is demonstrated, the assignation of a product into the paraprobiotic category should not be influenced by the methods used for microbial cell inactivation, which may be achieved using physical or chemical strategies, including heat treatment, $\gamma$ or UV ray deactivation, chemical or mechanical disruption, pressure, lyophilisation or acid deactivation.

In conclusion, the preparations included in the new paraprobiotic definition, namely, non-viable material of microbial origin, have been demonstrated to positively affect human/animal health, and they have the noticeable advantage over probiotics of allowing for the generation of safer and more stable products. Consequently, paraprobiotics are gaining in popularity and will be widely used in food, supplements, medicine and feed in the future.

\section{References}

Adams CA (2010) The probiotic paradox: live and dead cells are biological response modifiers. Nutr Res Rev 23:37-46

Agence Française de Sécurité Sanitaire des Aliments (2005) Effets des probiotiques et prébiotiques sur la flore et l'immunité de l'homme adulte. US Probiotics Web Site. http://www. usprobiotics.org/docs/AFFSA\%20probiotic\%20prebiotic\%20 flora\%20immunity\%2005.pdf. Accessed 12 March 2011

Agrawal S, Kandimalla ER (2002) Medicinal chemistry and therapeutic potential of CpG DNA. Trends Mol Med 8:114-121

Ananta E, Knorr D (2009) Comparison of inactivation pathways of thermal or high pressure inactivated Lactobacillus rhamnosus ATCC 53103 by flow cytometry analysis. Food Microbiol 26:542-546

Avall-Jääskeläinen S, Palva A (2005) Lactobacillus surface layers and their applications. FEMS Microbiol Rev 29:511-529

BCC Research (2008) The probiotic market: ingredients, supplements, foods (FOD035B). BCC Research web site. http://www. 
bccresearch.com/pressroom/FOD035B.html. Accessed 13 March 2011

Bergonzelli GE, Granato D, Pridmore RD, Marvin-Guy LF, Donnicola D, Corthésy-Theulaz IE (2006) GroEL of Lactobacillus johnsonii La1 (NCC 533) is cell surface associated: potential role in interactions with the host and the gastric pathogen Helicobacter pylori. Infect Immun 74:425-434

Besselink MG, van Santvoort HC, Buskens E et al (2008) Probiotic prophylaxis in predicted severe acute pancreatitis: a randomised, double-blind, placebo-controlled trial. Lancet 371:651-659

Bibiloni R, Fedorak RN, Tannock GW, Madsen KL, Gionchetti P, Campieri M, De Simone C, Sartor RB (2005) VSL\#3 probioticmixture induces remission in patients with active ulcerative colitis. Am J Gastroenterol 100:1539-1546

Björck P, Banchereau J, Flores-Romo L (1997) CD40 ligation counteracts Fas-induced apoptosis of human dendritic cells. Int Immunol 9:365-372

Cella M, Scheidegger D, Palmer-Lehmann K, Lane P, Lanzavecchia A, Alber G (1996) Ligation of CD40 on dendritic cells triggers production of high levels of interleukin-12 and enhances $\mathrm{T}$ cell stimulatory capacity: T-T help via APC activation. J Exp Med 184:747-752

Chapot-Chartier MP, Vinogradov E, Sadovskaya I, Andre G, Mistou MY, Trieu-Cuot P, Furlan S, Bidnenko E, Courtin P, Péchoux C, Hols P, Dufrêne YF, Kulakauskas S (2010) Cell surface of Lactococcus lactis is covered by a protective polysaccharide pellicle. J Biol Chem 285(14):10464-10471

Chuang L, Wu KG, Pai C, Hsieh PS, Tsai JJ, Yen JH, Lin MY (2007) Heat-killed cells of lactobacilli skew the immune response toward $\mathrm{T}$ helper 1 polarization in mouse splenocytes and dendritic cell-treated T cells. J Agric Food Chem 55:11080 11086

Corominas M, Mestre M, Bas J, Buendia E (1998) Distinct modulation by interferon-gamma (IFN-gamma) of CD23 expression on $\mathrm{B}$ and $\mathrm{T}$ lymphocytes of atopic subjects. Clin Exp Immunol 112:276-280

Cross ML, Ganner A, Teilab D, Fray LM (2004) Patterns of cytokine induction by gram-positive and gram-negative probiotic bacteria. FEMS Immunol Med Microbiol 42:173-180

De Simone C, Bianchi Salvadori B, Negri R, Ferrazzi M, Baldinelli L, Vesely R (1986) The adjuvant effect of yogurt on production of gamma-interferon by Con A-stimulated human peripheral blood lymphocytes. Nutr Rep Int 33:419-433

Di Giacinto C, Marinaro M, Sanchez M, Strober W, Boirivant M (2005) Probiotics meliorate recurrent Th1-mediated murine colitis by inducing IL-10 and IL-10-dependent TGF-beta-bearing regulatory cells. J Immunol 174(6):3237-3246

FAO/WHO (2002) Report of a joint FAO/WHO expert consultation on guidelines for the evaluation of probiotics in food. World Health Organization and Food and Agriculture Organization of the United Nations, London Ontario, Canada

Fedorak RN, Madsen KL (2004a) Probiotics and prebiotics in gastrointestinal disorders. Curr Opin Gastroenterol 20:146-155

Fedorak RN, Madsen KL (2004b) Probiotics and the management of inflammatory bowel disease. Inflamm Bowel Dis 10:286-299

Frotscher B, Anton K, Worm M (2002) Inhibition of IgE production by the imidazoquinoline resiquimod in nonallergic and allergic donors. J Invest Dermatol 119:1059-1064

Girardin SE, Boneca IG, Carneiro LA, Antignac A, Jehanno M, Viala $\mathrm{J}$, Tedin K, Taha MK, Labigne A, Zahringer U, Coyle AJ, DiStefano PS, Bertin J, Sansonetti PJ, Philpott DJ (2003) Nod1 detects a unique muropeptide from Gram-negative bacterial peptidoglycan. Science 300:1584-1587

Gobbetti M, Cagno RD, De Angelis M (2010) Functional microorganisms for functional food quality. Crit Rev Food Sci Nutr 50:716-727
Grozdanov L, Zähringer U, Blum-Oehler G, Brade L, Henne A, Knirel YA, Schombel U, Schulze J, Sonnenborn U, Gottschalk G, Hacker J, Rietschel ET, Dobrindt U (2002) A single nucleotide exchange in the wzy gene is responsible for the semirough O6 lipopolysaccharide phenotype and serum sensitivity of Escherichia coli strain Nissle 1917. J Bacteriol 184:5912-5925

Guglielmetti S, Tamagnini I, Mora D, Minuzzo M, Scarafoni A, Arioli S, Hellman J, Karp M, Parini C (2008) Implication of an outer surface lipoprotein in adhesion of Bifidobacterium bifidum to Caco-2 cells. Appl Environ Microbiol 74:4695-4702

Guglielmetti S, Taverniti V, Minuzzo M, Arioli S, Zanoni I, Stuknyte M, Granucci F, Karp M, Mora D (2010) A dairy bacterium displays in vitro probiotic properties for the pharyngeal mucosa by antagonizing group A streptococci and modulating the immune response. Infect Immun 78:4734-4743

Haller D, Bode C, Hammes WP, Pfeifer AM, Schiffrin EJ, Blum S (2000) Non-pathogenic bacteria elicit a differential cytokine response by intestinal epithelial cell/leucocyte co-cultures. Gut 47:79-87

Hart AL, Lammers K, Brigidi P, Vitali B, Rizzello F, Gionchetti P, Campieri M, Kamm MA, Knight SC, Stagg AJ (2004) Modulation of human dendritic cell phenotype and function by probiotic bacteria. Gut 53:1602-1609

Health Canada (2009). Guidance Document: The Use of Probiotic Microorganisms in Food. Health Canada web site. http://www.hc-sc.gc.ca/fn-an/alt_formats/hpfb-dgpsa/pdf/ legislation/probiotics_guidance-orientation_probiotiqueseng.pdf. Accessed 12 March 2011

Jensen GS, Benson KF, Carter SG, Endres JR (2010) GanedenBC30 cell wall and metabolites: anti-inflammatory and immune modulating effects in vitro. BMC Immunol 11:1-15

Kaji R, Kiyoshima-Shibata J, Nagaoka M, Nanno M, Shida K (2010) Bacterial teichoic acids reverse predominant IL-12 production induced by certain lactobacillus strains into predominant IL-10 production via TLR2-dependent ERK activation in macrophages. J Immunol 184:3505-3513

Kataria J, Li N, Wynn JL, Neu J (2009) Probiotic microbes: do they need to be alive to be beneficial? Nutr Rev 67:546-550

Kim HG, Lee SY, Kim NR, Lee HY, Ko MY, Jung BJ, Kim CM, Lee JM, Park JH, Han SH, Chung DK (2011) Lactobacillus plantarum lipoteichoic acid down-regulated Shigella flexneri peptidoglycan-induced inflammation. Mol Immunol 48:382-391

Kiniwa M, Gately M, Gubler U, Chizzonite R, Fargeas C, Delespesse G (1992) Recombinant interleukin-12 suppresses the synthesis of immunoglobulin E by interleukin-4 stimulated human lymphocytes. J Clin Invest 90:262-966

Konstantinov SR, Smidt H, de Vos WM, Bruijns SC, Singh SK, Valence F, Molle D, Lortal S, Altermann E, Klaenhammer TR, van Kooyk Y (2008) S layer protein A of Lactobacillus acidophilus NCFM regulates immature dendritic cell and T cell functions. Proc Natl Acad Sci USA 105:19474-19479

Lammers KM, Brigidi P, Vitali B, Gionchetti P, Rizzello F, Caramelli E, Matteuzzi D, Campieri M (2003) Immunomodulatory effects of probiotic bacteria DNA: IL-1 and IL-10 response in human peripheral blood mononuclear cells. FEMS Immunol Med Microbiol 38:165-172

Lebeer S, Vanderleyden J, De Keersmaecker SC (2010) Host interactions of probiotic bacterial surface molecules: comparison with commensals and pathogens. Nat Rev Microbiol 8:171-184

Lee JH, O'Sullivan DJ (2010) Genomic insights into bifidobacteria. Microbiol Mol Biol Rev 74:378-416

Lim LH, Li HY, Huang CH, Lee BW, Lee YK, Chua KY (2009) The effects of heat-killed wild-type Lactobacillus casei Shirota on allergic immune responses in an allergy mouse model. Int Arch Allergy Immunol 148:297-304 
Lopez M, Li N, Kataria J, Russell M, Neu J (2008) Live and ultraviolet-inactivated Lactobacillus rhamnosus GG decrease flagellin-induced interleukin-8 production in Caco- 2 cells. J Nutr 138:2264-2268

Lutz MB, Schuler G (2002) Immature, semi-mature and fully mature dendritic cells: which signals induce tolerance or immunity? Trends Immunol 23:445-449

Majamaa H, Isolauri E (1997) Probiotics: a novel approach in the management of food allergy. J Allergy Clin Immunol 99:179-185

Manetti R, Gerosa F, Giudizi MG, Biagiotti R, Parronchi P, Piccinni MP, Sampognaro S, Maggi E, Romagnani S, Trinchieri G et al (1994) Interleukin 12 induces stable priming for interferon gamma (IFN-gamma) production during differentiation of human $\mathrm{T}$ helper (Th) cells and transient IFN-gamma production in established Th2 cell clones. J Exp Med 179:1273-1283

Marteau P, Shanahan F (2003) Basic aspects and pharmacology of probiotics: an overview of pharmacokinetics, mechanisms of action and side-effects. Best Pract Res Clin Gastroenterol 17:725-740

Mastrangeli G, Corinti S, Butteroni C, Afferni C, Bonura A, Boirivant M, Colombo P, Di Felice G (2009) Effects of live and inactivated VSL\#3 probiotic preparations in the modulation of in vitro and in vivo allergen-induced Th2 responses. Int Arch Allergy Immunol 150:133-143

Matsuguchi T, Takagi A, Matsuzaki T, Nagaoka M, Ishikawa K, Yokokura T, Yoshikai Y (2003) Lipoteichoic acids from Lactobacillus strains elicit strong tumor necrosis factor alphainducing activities in macrophages through Toll-like receptor 2. Clin Diagn Lab Immunol 10:259-266

Matsuzaki T, Chin J (2000) Modulating immune responses with probiotic bacteria. Immunol Cell Biol 78:67-73

Medina M, Izquierdo E, Ennahar S, Sanz Y (2007) Differential immunomodulatory properties of Bifidobacterium longum strains: relevance to probiotic selection and clinical applications. Clin Exp Immunol 150:531-538

Miettinen M, Vuopio-Varkila J, Varkila K (1996) Production of human tumor necrosis factor alpha, interleukin-6, and interleukin-10 is induced by lactic acid bacteria. Infect Immun 64:5403-5405

Ministero della Salute (2005) Linee guida probiotici e probiotici. Ministero della Salute Web Site. http://www.salute.gov.it/ imgs/C_17_pubblicazioni_1016_allegato.pdf. Accessed 12 March 2011

Morris SC, Madden KB, Adamovicz JJ, Gause WC, Hubbard BR, Gately MK, Finkelman FD (1994) Effects of IL-12 on in vivo cytokine gene expression and $\mathrm{Ig}$ isotype selection. J Immunol 152:1047-1056

Murosaki S, Yamamoto Y, Ito K, Inokuchi T, Kusaka H, Ikeda H, Yoshikai Y (1998) Heat-killed Lactobacillus plantarum L-137 suppresses naturally fed antigen-specific IgE production by stimulation of IL-12 production in mice. J Allergy Clin Immunol 102:57-64

Muscettola M, Massai L, Tanganelli C, Grasso G (1994) Effects of lactobacilli on interferon production in young and aged mice. Ann N Y Acad Sci 717:226-232

Nahra R, Dellinger RP (2008) Targeting the lipopolysaccharides: still a matter of debate? Curr Opin Anaesthesiol 21:98-104

O'Connell Motherway M, O'Driscoll J, Fitzgerald GF, Van Sinderen D (2009) Overcoming the restriction barrier to plasmid transformation and targeted mutagenesis in Bifidobacterium breve UCC2003. Microb Biotechnol 2(3):321-332

Opal SM (2010) Endotoxins and other sepsis triggers. Contrib Nephrol 167:14-24

Philpott DJ, Girardin SE (2004) The role of Toll-like receptors and Nod proteins in bacterial infection. Mol Immunol 41:1099-1108
Rachmilewitz D, Karmeli F, Takabayashi K, Hayashi T, Leider-Trejo L, Lee J, Leoni LM, Raz E (2002) Immunostimulatory DNA ameliorates experimental and spontaneous murine colitis. Gastroenterology 122:1428-1441

Rachmilewitz D, Katakura K, Karmeli F, Hayashi T, Reinus C, Rudensky B, Akira S, Takeda K, Lee J, Takabayashi K, Raz E (2004) Toll-like receptor 9 signaling mediates the anti-inflammatory effects of probiotics in murine experimental colitis. Gastroenterology 126:520-528

Rasche C, Wolfram C, Wahls M, Worm M (2007) Differential immunomodulating effects of inactivated probiotic bacteria on the allergic immune response. Acta Derm Venereol 87:305-311

Reuter G (1997) Present and future probiotics in Germany and in Center Europe. Biosci Microflora 16:43-51

Ruas-Madiedo P, Moreno JA, Salazar N, Delgado S, Mayo B, Margolles A, de Los Reyes-Gavilán CG (2007) Screening of exopolysaccharide-producing Lactobacillus and Bifidobacterium strains isolated from the human intestinal microbiota. Appl Environ Microbiol 73(13):4385-4388

Ryan KA, Daly P, Li Y, Hooton C, O'Toole PW (2008) Strainspecific inhibition of Helicobacter pylori by Lactobacillus salivarius and other lactobacilli. J Antimicrob Chemother 61:831-834

Ryan KA, O'Hara AM, van Pijkeren JP, Douillard FP, O'Toole PW (2009) Lactobacillus salivarius modulates cytokine induction and virulence factor gene expression in Helicobacter pylori. J Med Microbiol 58:996-1005

Salminen S, Ouwehand A, Benno Y, Lee YK (1999) Probiotics: how should they be defined. Trends Food Sci Technol 10:107-110

Sartor RB (2005) Probiotic therapy of intestinal inflammation and infections. Curr Opin Gastroenterol 21:44-50

Shida K, Kiyoshima-Shibata J, Nagaoka M, Watanabe K, Nanno M (2006) Induction of interleukin-12 by Lactobacillus strains having a rigid cell wall resistant to intracellular digestion. J Dairy Sci 89:3306-3317

Smits HH, Engering A, de Jong EC, Schipper K, van Capel TM, Zaat BA, Yazdanbakhsh M, Wierenga EA, van Kooyk Y, Kapsenberg ML (2005) Selective probiotic bacteria induce IL-10-producing regulatory $\mathrm{T}$ cells in vitro by modulating dendritic cell function through dendritic cell-specific intercellular adhesion molecule 3-grabbing nonintegrin. J Allergy Clin Immunol 115:1260-1267

Stagg AJ, Bell SJ, Rigby R et al (2000) Treatment with antiTNFalpha antibody reduces expression of CD40 on lamina propria dendritic cells. Gastroenterology 118:A353

Tejada-Simon MV, Pestka JJ (1999) Proinflammatory cytokine and nitric oxide induction in murine macrophages by cell wall and cytoplasmic extracts of lactic acid bacteria. J Food Prot 62:1435-1444

Tohno M, Shimosato T, Kitazawa H, Katoh S, Iliev ID, Kimura T, Kawai Y, Watanabe K, Aso H, Yamaguchi T, Saito T (2005) Toll-like receptor 2 is expressed on the intestinal $\mathrm{M}$ cells in swine. Biochem Biophys Res Commun 330:547-554

Torii A, Torii S, Fujiwara S, Tanaka H, Inagaki N, Nagai H (2007) Lactobacillus acidophilus strain L-92 regulates the production of Th1 cytokine as well as Th2 cytokines. Allergol Int 56:293-301

Trebichavsky I, Splichal I, Rada V, Splichalova A (2010) Modulation of natural immunity in the gut by Escherichia coli strain Nissle 1917. Nutr Rev 68:459-464

van Hoffen E, Korthagen NM, de Kivit S, Schouten B, Bardoel B, Duivelshof A, Knol J, Garssen J, Willemsen LE (2010) Exposure of intestinal epithelial cells to UV-killed Lactobacillus GG but not Bifidobacterium breve enhances the effector immune response in vitro. Int Arch Allergy Immunol 152:159-168

Vidal K, Donnet-Hughes A, Granato D (2002) Lipoteichoic acids from Lactobacillus johnsonii strain La1 and Lactobacillus acidophilus strain La10 antagonize the responsiveness of human 
intestinal epithelial HT29 cells to lipopolysaccharide and Gramnegative bacteria. Infect Immun 70:2057-2064

Warshakoon HJ, Hood JD, Kimbrell MR, Malladi S, Wu WY, Shukla NM, Agnihotri G, Sil D, David SA (2009) Potential adjuvantic properties of innate immune stimuli. Hum Vaccin 5:381-394

Weiner HL (2001a) Oral tolerance: immune mechanisms and the generation of Th3-type TGF-beta-secreting regulatory cells. Microbes Infect 3:947-954

Weiner HL (2001b) The mucosal milieu creates tolerogenic dendritic cells and $\mathrm{T}(\mathrm{R}) 1$ and $\mathrm{T}(\mathrm{H}) 3$ regulatory cells. Nat Immunol 2:671-672
Yi AK, Yoon JG, Yeo SJ, Hong SC, English BK, Krieg AM (2002) Role of mitogen-activated protein kinases in CpG DNA-mediated IL-10 and IL-12 production: central role of extracellular signal-regulated kinase in the negative feedback loop of the $\mathrm{CpG}$ DNA-mediated Th1 response. J Immunol 168:4711-4720

Zhang L, Li N, Caicedo R, Neu J (2005) Alive and dead Lactobacillus rhamnosus GG decrease TNF- $\alpha$-induced interleukin- 8 production in Caco-2 cells. J Nutr 135:1752-1756 